\title{
Leaching of ashes from co-combustion of sewage sludge and wood \\ Part I: Recovery of phosphorus
}

\author{
Anita Pettersson ${ }^{1 *}$, Lars-Erik Åmand ${ }^{2}$, Britt-Marie Steenari ${ }^{3}$ \\ ${ }^{1}$ University College of Borås, SE-501 90 Borås, Sweden \\ ${ }^{2}$ Department of Energy and Environment, \\ Chalmers University of Technology \\ SE-412 96 Göteborg, Sweden \\ ${ }^{3}$ Department of Chemical and Biological Engineering \\ Chalmers University of Technology \\ SE-412 96 Göteborg, Sweden
}

\begin{abstract}
* Corresponding author: Tel.+46-33-435 59 82;
Mob. +46-70-736 31 82; Fax +46-33-435 4008

E-mail address: anita.pettersson@hb.se
\end{abstract}

\begin{abstract}
Combustion of sewage sludge with subsequent recovery of phosphorous is a relatively new sludge treatment option. In the work described in this paper, recovery of phosphorus by acid leaching of fly-ashes from co-combustion of sewage sludge with wood in a circulating fluidized bed combustor was investigated. The results showed that it is possible to find a $\mathrm{pH}$ range $(0.5-1)$ in which it is possible to extract a significant fraction of the phosphorous from these ashes without precipitation of secondary phosphates. The type of flocculation agent used in the waste water treatment plant where the sludge is formed has a significant effect on the phosphorous recovery. Ashes from combustion of sewage sludge that was formed using aluminium sulphate as flocculating agent released nearly all phosphorus at a $\mathrm{pH}$-value of 1 . When iron sulphate was used as flocculating agent, this affected the chemistry of the resulting ashes, making phosphorous recovery more difficult. The yield of phosphorous from those ashes was $50-80 \%$. In part II of the project [1] focus is on the trace element release to the leachate. This determines if the leachate can be used directly as a fertiliser or if further removal of trace elements is necessary.
\end{abstract}

Sludge, biofuel, phosphorus, leaching, co-combustion and fluidized bed 


\section{Introduction}

Apatite minerals are the main raw materials used in the manufacturing of fertilisers. However, the resources of apatite in the world are estimated to last only for about 200 years [2]. Therefore, sustainable methods to recycle the phosphorus used in the society are needed. One way of recycling could be to use the sewage sludge as fertiliser on arable land after a digestion step. The sludge contains considerable amounts of phosphorus, together with organic matter and other plant nutrients such as nitrogen, sulphur and potassium. However, it also contains residues formed from the addition of precipitating agents in the water treatment, organic contaminants and potentially toxic trace elements, such as arsenic (As), mercury $(\mathrm{Hg})$ and cadmium $(\mathrm{Cd})$. These metals may get enriched in the soil in the long run if the sludge is used directly as fertiliser [3].

Another option may be to incinerate the digested sludge and use the ash for fertiliser production. Incineration with heat recovery will lead to a destruction of potentially harmful organic components. The inorganic components are transformed in various ways during combustion. Generally, the non-combustible residues resulting from a combustion unit are named bed ash and fly ash depending on the location at which the ash is collected. Variations in fuel composition, combustion technology and the conditions in the particle separation equipment affect the composition and properties of the different ash flows leaving the combustion unit. Generally, the phosphorus is enriched in the fly ash together with the trace elements. An important issue in the development of sludge ash utilisation strategies is whether the concentration of trace elements is low enough to allow the use of sludge ashes or products thereof as fertilisers [4].

Part of the energy content in the sewage sludge is utilised by digesting the sludge to form biogas (methane + carbon dioxide). However, the volume of residue remaining after biogas production is almost as large as that of the original sludge. In digestion the phosphorous remains in the residues and its recovery require an additional process to separate it. In some cases, when the original sludge has a low degree of contamination, the remaining digested sludge can be used directly for fertilizing purpose.

Recovery of phosphorous from sewage sludge can also be carried out through an extraction procedure. In the KREPRO process [5], sludge is hydrolysed at $140^{\circ} \mathrm{C}$ and 3.5 bar and phosphorous compounds are dissolved along with other components of the sludge. The phosphorus is recovered as iron phosphate that needs further treatment to become useful [6].

Extraction of phosphorous from the ash remaining after combustion of sewage sludge has also been suggested as a method to recover phosphorus. In the BioCon process [5; 6], the sludge is dried and incinerated with utilisation of the heat from the combustion in the drying step. The ash is ground and extracted with sulphuric acid. The recovery of phosphorus from the liquid phase is carried out using ion exchange techniques. The KREPRO process and the BioCon process both have the disadvantage that the volumes of chemicals used are rather large and none of them has been implemented in a commercial facility.

Recently, a new process has been suggested: the SEPHOS-process [7; 8]. In this process sludge ash is treated with sulphuric acid at $\mathrm{pH}<1.5$. The solids are separated and the $\mathrm{pH}$ in the remaining filtrate is step vice increased to $\mathrm{pH} 3.5$ by addition of caustic soda to separate 
phosphorus and heavy metals. By the increased $\mathrm{pH}$ the phosphorus is re-precipitated as aluminium phosphate.

The aim of the present work was to develop a simple phosphorous extraction method that could be applied to ash residues from combustion of sewage sludge. This investigation was part of a research project concerning the combustion of sewage sludge in fluidized bed boilers. Since sewage sludge has a low heating value, this was compensated for by adding a supplementary fuel. Wood is a particularly suitable supplementary fuel for sludge combustion since its low ash content causes a negligible contribution to the amount of ashes that have to be treated. The choice of sewage sludges was made with the aim to study how the precipitation agent (ferric sulphate or aluminium sulphate) influences the properties of the sludge ash and the possibility to recover phosphorous from it.

\section{Experimental background}

\subsection{The Boiler.}

The $12 \mathrm{MW}_{\text {th }}$ circulating fluidized bed (CFB) boiler at Chalmers University of Technology (Göteborg, Sweden) was used for the combustion tests, Figure 1.

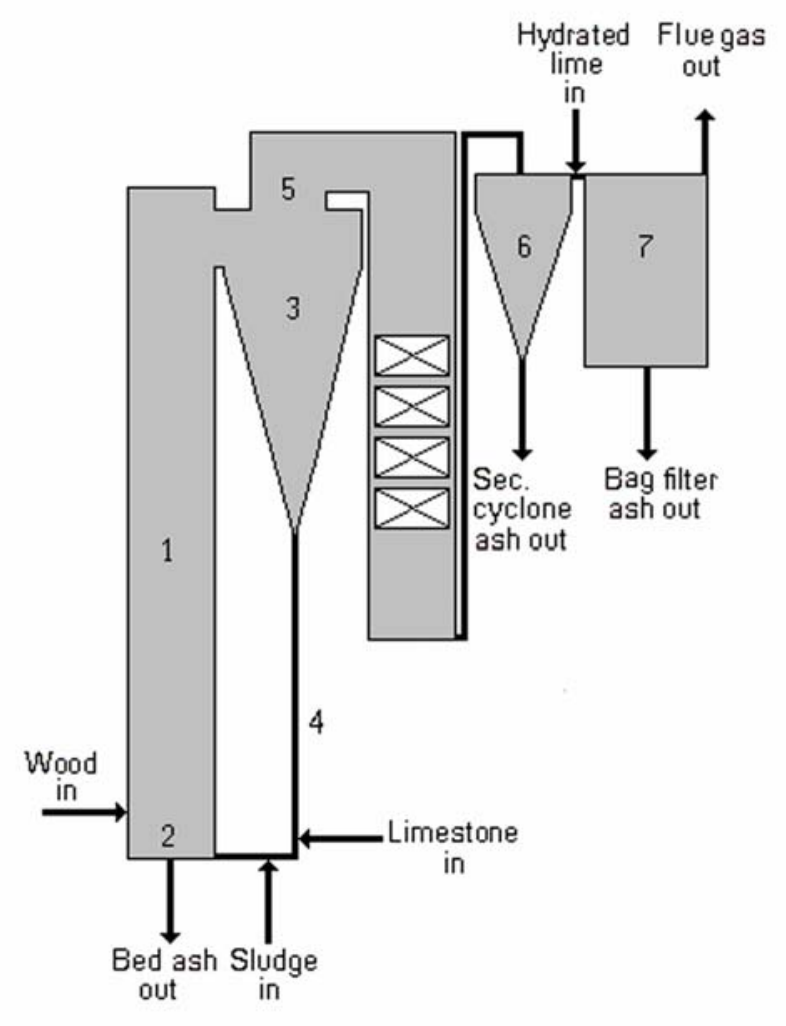

Figure 1: The 12-MW $\mathrm{MW}_{\text {th }}$ FBC boiler at Chalmers University of Technology. (1) combustion chamber, (2) bottom bed sampling location, (3) hot primary cyclone, (4) particle return leg, (5) cyclone exit duct, (6) secondary cyclone, (7) bag filter. 
The combustion chamber (1) has a square cross-section of about $2.25 \mathrm{~m}^{2}$ and a height of $13.6 \mathrm{~m}$. The supplementary fuel (wood pellets) is fed to the bottom of the combustion chamber through a fuel chute and the sewage sludge through the particle return leg (4). The mechanically dewatered sludge was supplied by a special sludge pump (rebuilt cement pump) to the particle seal where it was mixed with the hot particles coming from the primary cyclone before it entered into the combustion chamber. Part of the solids carried by the flue gas are separated in the primary cyclone and recirculated back to the combustion chamber (3) through the particle return leg (4) back into the combustion chamber. Primary combustion air is supplied to the bottom of the combustion chamber, and secondary air is injected through a nozzle register located just above the fuel chute. After passing the exit duct of the cyclone (5), the flue gases are cooled to $150^{\circ} \mathrm{C}$ in the convection path and about $80 \%$ of the coarsest size fraction of the fly ashes are separated from the flue gases in a secondary cyclone (6) and the remaining fraction of fines is captured in a textile bag filter (7). This is not a common arrangement in commercial CFB boilers, but it has the advantage of giving fly ash samples with different size distributions depending on the collection point. This gives the opportunity to study how the particle size distribution influences the characteristics of the ash.

\subsection{The Fuels.}

The base fuel was wood pellets, produced from sawdust from Swedish domestic trees like pine and birch. Wood pellets were chosen as base fuel in the tests because it is a well defined bio fuel with constant properties and low ash content. The additional fuels were two different municipal sewage sludges. In the first set of tests mechanically dewatered sludge from a large waste water treatment plant was used. This plant treats the waste water from a city with 775000 inhabitants. The second set of tests involved dewatered sludge from a smaller waste water treatment plant in a town of 35000 inhabitants. Both plants treat waste water from mainly households. On top of this household waste water, various industries are also connected to the sewage system. The two waste water treatment plants produce digested sludge, but employ different precipitation chemicals for phosphorus removal. The large plant utilizes ferric sulphate and the smaller plant aluminium sulphate. Table 1 shows the fuel analyses.

The co-combustion tests were performed with the same boiler load as during monofuelcombustion operation. Since the heating value of sludge is lower than that of wood, the mass flow of sludge was correspondingly larger than that of wood for the same thermal load. With a moisture content of $72-79 \%$ and an ash content of $42-46 \%$ on dry bases the lower heating value of the sludge becomes to low for mono-combustion. Co-firing with a fuel with higher heating value becomes necessary. Despite the dry and ash-free wood pellets a mixing ratio of $15 \%$ (on dry fuel) is an upper limit without sacrificing the same bottom bed temperature for all the tests. Pre-drying of the sludge would allow higher mixing ratios up to $100 \%$ sludge. 
Table 1: Properties of the sewage sludge and wood pellets.

\begin{tabular}{|c|c|c|c|c|}
\hline Precipitation as & Unit & $\begin{array}{l}\text { Sewage } \\
\text { sludge } \\
\mathrm{Fe}_{2}\left(\mathrm{SO}_{4}\right)_{3}\end{array}$ & $\begin{array}{l}\text { Sewage } \\
\text { sludge } \\
\mathrm{Al}_{2}\left(\mathrm{SO}_{4}\right)_{3}\end{array}$ & $\begin{array}{l}\text { Wood } \\
\text { pellets } \\
-\end{array}$ \\
\hline \multicolumn{5}{|c|}{ Proximate analysis } \\
\hline Water & wt-\%, raw & 72.0 & 77.8 & 8.0 \\
\hline Ash & wt- $\%$, dry & 46.0 & 42.6 & 0.4 \\
\hline Combustibles & wt- $\%$, dry & 54.0 & 57.4 & 99.6 \\
\hline Volatiles & wt- $\%$, daf & 94.4 & 85.3 & 81.7 \\
\hline \multicolumn{5}{|c|}{ Ultimate analysis } \\
\hline $\mathrm{C}$ & wt- $\%$, daf & 52.6 & 50.2 & 50.3 \\
\hline $\mathrm{H}$ & wt- $\%$, daf & 7.2 & 7.3 & 6.1 \\
\hline $\mathrm{N}$ & wt- $\%$, daf & 5.4 & 5.0 & 0.8 \\
\hline $\mathrm{S}$ & wt- $\%$, daf & 1.4 & 1.3 & 0.01 \\
\hline $\mathrm{Cl}$ & wt- $\%$, daf & 0.1 & 0.1 & 0.01 \\
\hline $\mathrm{O}$ & wt- $\%$, daf & 33.3 & 36.2 & 43.5 \\
\hline \multicolumn{5}{|c|}{ Heating value (MJ kg ${ }^{-1}$ ) } \\
\hline $\mathrm{HHV}$, daf & $\mathrm{MJ} \mathrm{kg}^{-1}$ & 20.5 & 19.5 & 18.8 \\
\hline LHV, raw & $\mathrm{MJ} \mathrm{kg}^{-1}$ & 2.78 & 2.24 & 17.2 \\
\hline \multicolumn{5}{|l|}{ Ash analysis } \\
\hline $\mathrm{K}$ & $\mathrm{g} \mathrm{kg}^{-1}$ dry ash & 13.3 & 10.7 & 82.0 \\
\hline $\mathrm{Na}$ & $\mathrm{g} \mathrm{kg}^{-1}$ dry ash & 7.28 & 6.9 & 6.7 \\
\hline $\mathrm{Al}$ & $\mathrm{g} \mathrm{kg}^{-1}$ dry ash & 73.3 & 193 & 12.2 \\
\hline $\mathrm{Si}$ & $\mathrm{g} \mathrm{kg}^{-1}$ dry ash & 127 & 115 & 79.7 \\
\hline $\mathrm{Fe}$ & $\mathrm{g} \mathrm{kg}^{-1}$ dry ash & 160 & 42.1 & 20.9 \\
\hline $\mathrm{Ca}$ & $\mathrm{g} \mathrm{kg}^{-1}$ dry ash & 40.0 & 38.0 & 164 \\
\hline $\mathrm{Mg}$ & $\mathrm{g} \mathrm{kg}^{-1}$ dry ash & 9.9 & 5.3 & 26.4 \\
\hline $\mathrm{P}$ & $\mathrm{g} \mathrm{kg}^{-1}$ dry ash & 58.6 & 61.3 & 12.7 \\
\hline $\mathrm{Ti}$ & $\mathrm{g} \mathrm{kg}^{-1}$ dry ash & 4.4 & 9.6 & 0.7 \\
\hline
\end{tabular}

\subsection{Experimental Procedure.}

Six combustion test series were carried out, each consisting of three cases. Each series included a reference case when only wood pellets were fired. In the second series, $7 \%$ of the total dry mass of the fuel was sludge, and in the third series the sludge fraction was $15 \%$. The investigation about recovery of phosphorous was focussed on the ashes from the tests with $15 \%$ sludge. In this paper, the tests are named after the origin of the sludge: Fe for sludge precipitated with ferric sulphate and $\mathrm{Al}$ for sludge precipitated with aluminium sulphate, with a suffix relating to the lime addition strategy. In the series "Fe+no lime" and "Al+no lime", no lime was added to the combustion chamber and the emissions of sulphur dioxide $\left(\mathrm{SO}_{2}\right)$ and hydrogen chloride $(\mathrm{HCl})$ reached values that reflect the concentrations of sulphur and chlorine in the fuel. In the series "Fe+limestone" and " $\mathrm{Al}+$ limestone", limestone $\left(\mathrm{CaCO}_{3}\right)$ was added to the bed to capture sulphur as $\mathrm{CaSO}_{4}$, and in the series "Fe+hydr. lime" and "Al+hydr. lime", hydrated lime $\left(\mathrm{Ca}(\mathrm{OH})_{2}\right)$ was injected into the flue gas upstream of the bag filter to investigate its effect on ash composition and emissions of $\mathrm{HCl}$ and $\mathrm{SO}_{2}$. Table 2 summarizes the test conditions. 
Table 2: Test matrix.

\begin{tabular}{llccc}
\hline $\begin{array}{l}\text { Test } \\
\text { names }\end{array}$ & $\begin{array}{l}\text { Precipitation } \\
\text { agent }\end{array}$ & No Lime & $\begin{array}{c}\text { Lime to } \\
\text { bed }\end{array}$ & $\begin{array}{l}\text { Hydrated lime } \\
\text { to bag filter }\end{array}$ \\
\hline $\mathrm{Fe}+$ no lime & $\mathrm{Fe}_{2}\left(\mathrm{SO}_{4}\right)_{3}$ & $\mathrm{X}$ & & \\
$\mathrm{Al}+$ no lime & $\mathrm{Al}_{2}\left(\mathrm{SO}_{4}\right)_{3}$ & $\mathrm{X}$ & & \\
$\mathrm{Fe}+$ limestone & $\mathrm{Fe}_{2}\left(\mathrm{SO}_{4}\right)_{3}$ & & $\mathrm{X}$ & \\
$\mathrm{Al}+$ limestone & $\mathrm{Al}_{2}\left(\mathrm{SO}_{4}\right)_{3}$ & & $\mathrm{X}$ & \\
$\mathrm{Fe}+$ hydr. lime & $\mathrm{Fe}_{2}\left(\mathrm{SO}_{4}\right)_{3}$ & & & $\mathrm{X}$ \\
$\mathrm{Al}+$ hydr. lime & $\mathrm{Al}_{2}\left(\mathrm{SO}_{4}\right)_{3}$ & & & $\mathrm{X}$ \\
\hline
\end{tabular}

The boiler operating conditions are presented in Table 3 . They were chosen to represent a typical CFB boiler and kept similar in all tests. After each change of fuel composition and lime addition method an equilibration time of 12 hours [4] was allowed before the solid samples for analysis were collected, in order to establish steady-state concentrations of the trace elements. In each test the following samples were taken (for locations see Figure 1); wood pellets and sludge before entering the boiler, bottom bed material (2), ash from the cyclone leg (4), ash collected in the secondary cyclone (6) and bag filter ash (7).

Table 3: Operating conditions [9].

\begin{tabular}{|c|c|c|c|c|c|c|c|}
\hline & Unit & $\begin{array}{l}\text { Wood/Sludge } \\
\text { Fe+no lime }\end{array}$ & $\begin{array}{l}\text { Wood/Sludge } \\
\text { Al+no lime }\end{array}$ & $\begin{array}{l}\text { Wood/Sludge }^{1} \\
\text { Fe+limestone }\end{array}$ & $\begin{array}{l}\text { Wood/Sludge } \\
\text { Al+limestone }\end{array}$ & $\begin{array}{l}\text { Wood/Sludge } \\
\text { Fe+hydr. lime }\end{array}$ & $\begin{array}{l}\text { Wood/Sludge } \\
\text { Al+hydr. lime }\end{array}$ \\
\hline Load, $\mathrm{MW}_{\text {th }}$ & $\mathrm{MW}_{\text {th }}$ & 6.1 & 6.0 & 6.0 & 6.4 & 6.0 & 6.0 \\
\hline Bed temp. & ${ }^{\circ} \mathrm{C}$ (bottom) & 848 & 843 & 852 & 850 & 850 & 848 \\
\hline Bed temp. & ${ }^{\circ} \mathrm{C}$ (top) & 866 & 880 & 852 & 856 & 882 & 870 \\
\hline \multicolumn{8}{|l|}{ Exit temp. of after } \\
\hline combustion chamber & ${ }^{\circ} \mathrm{C}$ & 849 & 855 & 865 & 861 & 828 & 834 \\
\hline Total riser pressure drop & $\mathrm{kPa}$ & 6.4 & 6.4 & 6.5 & 6.3 & 6.6 & 6.3 \\
\hline Calcium addition molar ratio $\mathrm{Ca} / \mathrm{S}$ & & 0.0 & 0.0 & 1.7 & 2.7 & 4.6 & 5.0 \\
\hline $\mathrm{Ca} / \mathrm{S}$ with $\mathrm{Ca}$ in fuel included & & 1.9 & 1.9 & 3.7 & 4.7 & 6.3 & 7.2 \\
\hline Excess air ratio & & 1.2 & 1.2 & 1.2 & 1.2 & 1.2 & 1.3 \\
\hline Primary air flow/total air flow & $\%$ & 57 & 50 & 59 & 59 & 57 & 57 \\
\hline $\begin{array}{l}\text { Superficial flue gas velocity } \\
\text { at top of riser } U_{\text {top }}\end{array}$ & $\mathrm{m} \mathrm{s}^{-1}$ & 5.3 & 5.2 & 5.2 & 5.4 & 4.9 & 5.0 \\
\hline
\end{tabular}

(1)= Large plant; (2)= Small plant.

\subsection{Chemical analyse.}

The contents of moisture and combustibles in the fuels and ash samples were determined using a LECO MAC 400 Proximate Analyzer 785-700 system. Ultimate analysis was performed by using an external accredited laboratory (SP, Swedish Testing and Research Institute). X-ray Fluorescence (XRF) was used for the determination of the main ash elements.

\subsection{Ash extraction procedure.}

All ash extraction experiments were carried out at room temperature in a $718 \mathrm{pH}-\mathrm{STAT}$ Titration unit (Metrohm Ltd.) with continuous $\mathrm{pH}$ measurement and automatic compensation for the release of alkaline components by addition of sulphuric acid. The investigated $\mathrm{pH}$-range was $\mathrm{pH}$ $0.5-2.5$. Each experiment was started with $0.4 \mathrm{~g}$ of ash and $60 \mathrm{ml}$ of water, i.e. a mass ratio of solid to liquid of $1: 150$. The additions of acid required to keep the $\mathrm{pH}$ at the chosen level was logged. The experiments had duration of 90 minutes, based on experience from pre-tests. In 
addition, the length of this extraction time was considered relevant for real processes. After the leaching experiment, the slurries were separated into a solid part and a leachate by filtering through a membrane filter with a pore size of $45 \mu \mathrm{m}$. A second series of experiments were carried out in the same way as described above but with less liquid giving a mass ratio of solids to liquid of $1: 8$.

The choice of sulphuric acid as the extraction medium was based on the fact that there are not many soluble sulphate complexes of trace metals formed. Hydrochloric acid would add chloride ions to the leachate and these could form soluble complexes with most heavy metals, thus increasing the amount of metals in solution. Yoshizaki and Tomida [10], studied removal of trace metals from sewage sludge by both hydrochloric acid and sulphuric acid in the pH-range 0.8-1.5. They found that at room temperature, leaching during 1 hour gave a larger release of trace metals with hydrochloric acid than with sulphuric acid. The most significant difference concerned $\mathrm{Pb}$, were $\mathrm{HCl}$ released $100 \%$ and $\mathrm{H}_{2} \mathrm{SO}_{4}$ just $37 \%$ of the available $\mathrm{Pb}$ in the sludge [10].

The content of $\mathrm{PO}_{4}{ }^{3-}$ ions in the leachate was determined by a colorimetric method with a molybdenum reagent as well as by an Ion Chromatographic (IC) method. The total phosphorus content was determined by means of Inductively Coupled Plasma with Optical Emission Spectrometry (ICP-OES). The contents of main elements in the leachates were also determined by using ICP-OES.

\subsection{Chemical equilibrium calculations.}

Calculations of solubility equilibria in conditions similar to those applied in the leaching experiments were made using the Medusa/ Hydra program and the database version 31 [11]. The components considered were: aluminium, iron, phosphorus, calcium and potassium. All soluble and non-soluble complexes available in the database were allowed, provided that the chemistry behind their presence was reasonable.

\subsection{Electron Scanning Microscopy.}

The appearance and element distributions of ash samples and solid residues remaining after leaching and filtration were examined by Scanning Electron Microscopy (SEM) including Energy Dispersive X-ray Fluorescence analysis (EDX). The electron beam induces emission of element specific X-ray wave lengths and by programming the detector to scan the specimen surface, element "maps" can be obtained.

\subsection{Mineralogical analyses by $X$-ray powder diffractometry.}

The mineralogy of the ash samples was studied by X-ray Powder Diffraction (XRD), for the identification of the crystalline components. The instrument used in this work was a Siemens D5000 Powder Diffractometer applying $\mathrm{Cu}$ characteristic radiation and a scintillation detector. The Joint Committee of Powder Diffraction Standards database was used for identification of crystalline compounds. This method allows the identification of crystalline components present in amounts larger than $1-2 \%(\mathrm{w} / \mathrm{w})$. 


\section{Results and Discussion}

\subsection{Influence of sludge type and lime addition strategy on the ash flows}

The accuracy of the ash mass flow measurements was estimated by a total mass balance of solid material over the fluidized bed combustor under steady-state operating conditions. The input mass flow of fuel ash, lime and silica sand was compared with the exiting mass flows of bed and fly ash [12]. The release of volatiles from the ashes was neglected, but the conversion of lime and unburned char in the exit flows was taken into account. The resulting ash recovery fraction (ash out ash $\mathrm{in}^{-1}$ ) varied between 0.90 and 1.20 , which is good, considering the size of the boiler, see Table 4.

Table 4: The ash flows and ash recovery fraction for the different tests.

\begin{tabular}{lllcl}
\hline & $\begin{array}{l}\text { Bed } \\
\text { ash } \\
\mathrm{kg} \mathrm{h}^{-1}\end{array}$ & $\begin{array}{l}\text { Sec. cyclone } \\
\text { ash } \\
\mathrm{kg} \mathrm{h}^{-1}\end{array}$ & $\begin{array}{l}\text { Bag filter } \\
\text { ash } \\
\mathrm{kg} \mathrm{h}^{-1}\end{array}$ & $\begin{array}{l}\text { Ash recovery } \\
\text { Fraction } \\
\text { ash out ash in }\end{array}$ \\
\hline Wood & 17.4 & 4.9 & 3.6 & 0.87 \\
Fe+no lime & 19.7 & 79.2 & 8.4 & 1.04 \\
Fe+limestone & 27.5 & 94.3 & 10.7 & 1.05 \\
Fe+hydr.lime & 11.3 & 80.7 & 36.0 & 1.22 \\
Al+no lime & 46.9 & 45.8 & 5.7 & 1.03 \\
Al+limestone & 37.4 & 71.9 & 9.2 & 1.12 \\
Al+hydr.lime & 30.2 & 52.4 & 27.5 & 0.90 \\
\hline
\end{tabular}

The distribution of non-combustibles between bed and fly ash fractions in the combustion tests included in this work is given in Table 4. The bed ash flow is higher when combusting sludge precipitated with aluminium sulphate than when sludge precipitated with iron sulphate was used. The increased amount of ash introduced by the iron based sludge ends up in the cyclone ash, a fact that indicates formation of smaller ash particles than in case with the aluminium based sludge. The particle size distributions of typical ash samples are shown in Figure 2 [13]. The much smaller particle sizes of ash collected from the bag filter (about $1 / 10^{\text {th }}$ of the sizes of secondary cyclone ash particles) is clearly seen. The dominant ash flow in all tests is collected in the secondary cyclone, except for the test "Al+no lime" Table 4, in which the bed ash flow is similar to the flow of cyclone ash, and in the reference test "wood" in which the bed ash flow is dominating. The addition of hydrated lime to the bag filter increases the bag-filter ash flow by approximately a factor three. 

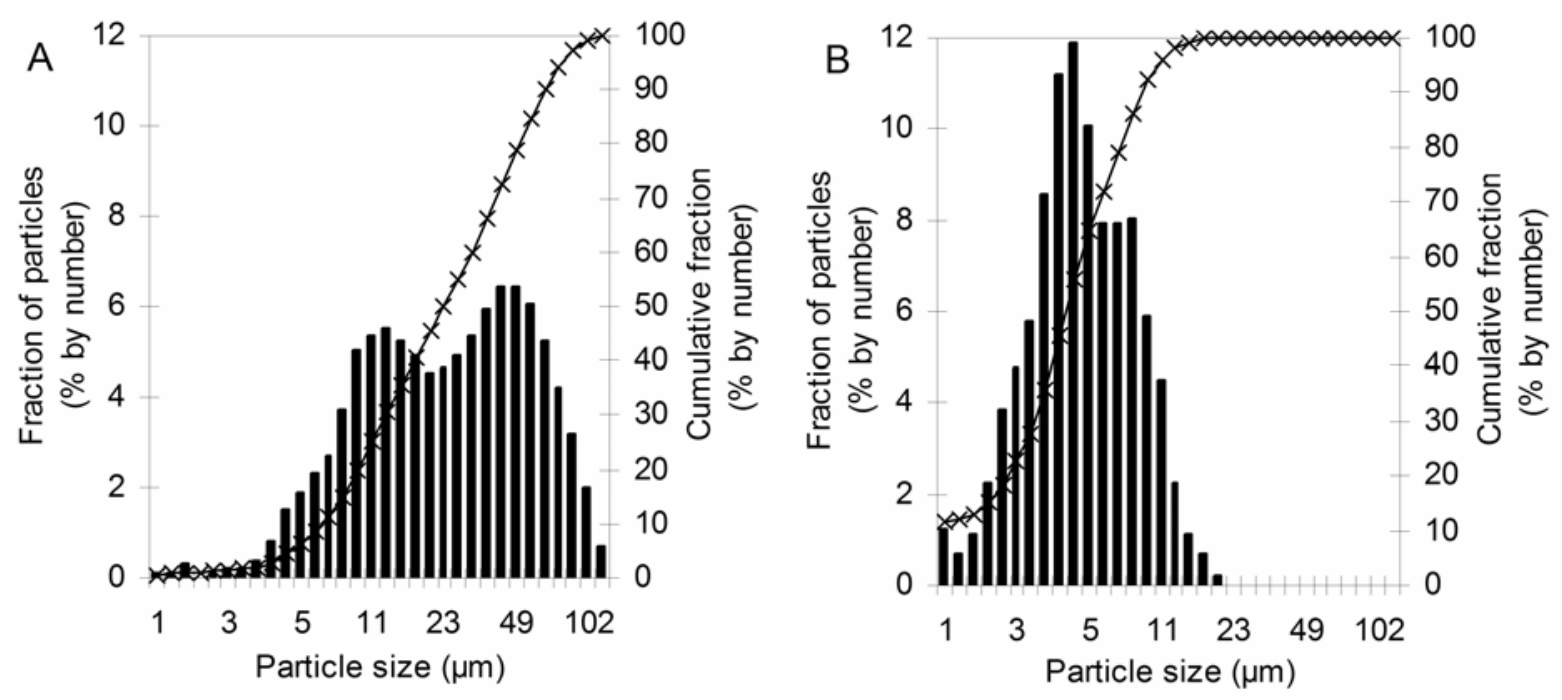

Figure 2: Particle size distribution (\% by number) for typical ashes from combustion cases Fe+no lime. (A) secondary cyclone ash, (B) bag filter ash. Lines- cumulative, bars - fractional distribution [13].

\subsection{Ash compositions.}

Table 5 gives the main elements concentrations in the three ash flows. Combining these concentrations with the ash flows of Table 4 gives the outgoing P-flows, Figure 3. From Figure 3 it is evident that the dominating outgoing P-flow is that with the secondary cyclone ash. Leaching of the bed ashes is therefore not relevant. This means that if phosphorous recovery is the focus then the secondary fly ash should be studied in more detail with the bag filter ash as a comparison.

Table 5: Main elements in the fly ashes.

\begin{tabular}{|c|c|c|c|c|c|c|c|c|c|c|c|c|}
\hline $\begin{array}{l}\text { Ash analysis } \\
\text { main elements } \\
\text { [g kg }{ }^{-1} \text { dry ash] }\end{array}$ & $\begin{array}{l}\text { Fe+no lime } \\
\text { sec. cyclone }\end{array}$ & bag filter & $\begin{array}{l}\text { Al+no lime } \\
\text { sec. cyclone }\end{array}$ & bag filter & $\begin{array}{l}\text { Fe+limeston } \\
\text { sec. cyclone }\end{array}$ & bag filter & $\begin{array}{l}\text { Al+limeston } \\
\text { sec. cyclone }\end{array}$ & bag filter & $\begin{array}{l}\text { Fe+hydr. lim } \\
\text { sec. cyclone }\end{array}$ & bag filter & $\begin{array}{l}\text { Al+hydr. lime } \\
\text { sec. cyclone }\end{array}$ & bag filter \\
\hline$\overline{\mathrm{K}}$ & 22 & 36 & 41 & 48 & 13 & 19 & 17 & 15 & 16 & 8.4 & 16 & 5.0 \\
\hline $\mathrm{Na}$ & 8.1 & 7.3 & 10 & 8.0 & 7.3 & 7.0 & 7.0 & 5.0 & 7.0 & 3.0 & 8.0 & 3.0 \\
\hline Al & 83 & 63 & 170 & 120 & 73 & 83 & 180 & 130 & 79 & 36 & 210 & 58 \\
\hline $\mathrm{Si}$ & 130 & 95 & 130 & 88 & 130 & 110 & 11 & 92 & 130 & 560 & 120 & 45 \\
\hline $\mathrm{Fe}$ & 180 & 180 & 41 & 29 & 160 & 190 & 46 & 77 & 180 & 81 & 47 & 21 \\
\hline $\mathrm{Ca}$ & 49 & 99 & 51 & 130 & 40 & 100 & 81 & 140 & 65 & 330 & 55 & 380 \\
\hline $\mathrm{Mg}$ & 10 & 24 & 18 & 28 & 9.4 & 19 & 7.0 & 18 & 11 & 14 & 8.2 & 13 \\
\hline$P$ & 66 & 57 & 60 & 39 & 60 & 56 & 59 & 51 & 66 & 23 & 63 & 17 \\
\hline $\mathrm{Ti}$ & 5.0 & 4.2 & 9.0 & 9.0 & 4.2 & 5.5 & 9.0 & 6.0 & 4.0 & 20 & 9.3 & 2.1 \\
\hline S & 2.0 & 18 & 3.0 & 35 & 12 & 17 & 4.0 & 22 & 65 & 16 & 2.0 & 18 \\
\hline
\end{tabular}

The phosphorous is not retained in the bed ash, but follows the incombustible residues from the fuel to the cyclone and the filter. In addition, the results in Table 5 show that the iron and aluminium remaining from the precipitation chemicals, as well as most of the remaining main elements of the fuel ash, can be found in the cyclone and filter ashes. 


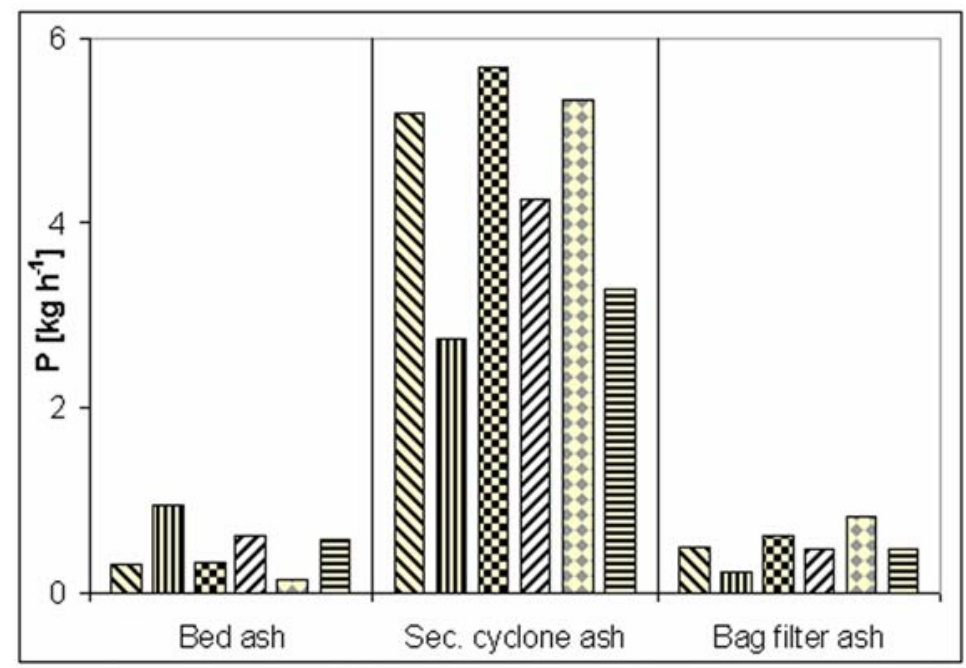

Figure 3: Phosphorus flows in the different ashes as $\mathrm{kg} / \mathrm{h}$ for the tests with $15 \%$ sludge as co-fuel.

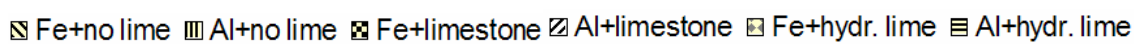

Depending on precipitation agent, the original form of phosphorus in the sludge prior to digestion is $\mathrm{FePO}_{4}$ or $\mathrm{AlPO}_{4}$. According to chemical equilibrium calculations [14], the phosphorus combines with calcium to form $\mathrm{Ca}_{3}\left(\mathrm{PO}_{4}\right)_{2}$ during combustion of both sludge types, if $\mathrm{Ca}$ is available.

A comparison of the molar ratios between $\mathrm{Ca}$ and $\mathrm{P}$ in the ash parts of the sludges and in the ashes shows that calcium is enriched relative to phosphorous during ash formation (Table 6). However, the cyclone ash generally does not contain enough calcium to indicate that the phosphorous would be present in $\mathrm{Ca}_{3}\left(\mathrm{PO}_{4}\right)_{2}$ only. The theoretical molar $\mathrm{Ca} / \mathrm{P}$ ratio would in that case have to be 1.5. The bag filter ashes, on the other hand, contain a surplus of calcium (except for the case $\mathrm{Fe}+$ no lime). The iron in iron sulphate treated sludge theoretically tends to form $\mathrm{Fe}_{2} \mathrm{O}_{3}$ (s) during combustion, whereas combustion of aluminium based sludge theoretically would result in a partial transformation of the aluminium phosphate to different aluminium silicates. Some aluminium could also be associated with phosphate in the ash, especially if there is a lack of $\mathrm{Ca}[14]$.

Table 6: $\mathrm{Ca}$ to $\mathrm{P}$ ratios in the sludges and ashes studied

\begin{tabular}{|c|c|c|c|c|c|c|c|}
\hline & $\begin{array}{l}\text { Fe-based sludge } \\
\text { Ash part of } \\
\text { the sludge }\end{array}$ & $\begin{array}{l}\text { Fe+no } \\
\text { sec. cyc }\end{array}$ & $\begin{array}{l}\text { me } \\
\text { bag filter }\end{array}$ & $\begin{array}{l}\mathrm{Fe}+\mathrm{lin} \\
\text { sec. cy }\end{array}$ & $\begin{array}{l}\text { mestone } \\
\text { cycl. bag filter }\end{array}$ & $\begin{array}{l}\text { Fe+hydr. } \\
\text { r sec. cycl. }\end{array}$ & $\begin{array}{l}\text { lime } \\
\text { bag filter }\end{array}$ \\
\hline $\begin{array}{c}\text { molar ratic } \\
\mathrm{Ca} \mathrm{P}^{-1}\end{array}$ & 0.54 & 0.81 & 1.4 & 1.17 & 1.65 & 1.01 & 7.73 \\
\hline & $\begin{array}{l}\text { Al-based sludge } \\
\text { Ash part of } \\
\text { the sludge }\end{array}$ & $\begin{array}{l}\text { Al+nol } \\
\text { sec. cyc }\end{array}$ & me bag filter & $\begin{array}{l}\text { Al+lim } \\
\text { sec. cy }\end{array}$ & $\begin{array}{l}\text { mestone } \\
\text { cycl. bag filter }\end{array}$ & $\begin{array}{l}\text { Al+hydr. } \\
\text { r sec. cycl. }\end{array}$ & $\begin{array}{l}\text { lime } \\
\text { bag filter }\end{array}$ \\
\hline $\begin{array}{l}\text { molar ratic } \\
\mathrm{Ca} \mathrm{P}^{-1}\end{array}$ & 0.48 & 0.62 & 3.14 & 1.17 & 2.21 & 0.71 & 6.7 \\
\hline
\end{tabular}

Results from the qualitative X-ray powder diffraction analysis, carried out for the original ash samples, are shown in Table 7. Haematite $\left(\mathrm{Fe}_{2} \mathrm{O}_{3}\right)$ was identified in all the Fe-rich ashes but also 
small amounts of $\mathrm{MgFeAlO}_{4}$. The phosphate found in these ashes contained both calcium and iron. This indicates that iron may not only be present as haematite after the combustion, a result given by the equilibrium calculations. Small amounts of haematite were found also in the bag filter ash "Al+limestone". Some of the calcium was found as calcium sulphate (product of the sulphur capture) and calcium carbonate (the original limestone that has not calcinated to $\mathrm{CaO}$ ), but most calcium was found together with the phosphate, which in this case was a calcium aluminium phosphate or calcium iron phosphate.

Table 7: Crystalline compounds found in ash samples from the different tests. $X=$ more and $x=$ less.

\begin{tabular}{|c|c|c|c|c|c|c|c|c|c|}
\hline Ash sample & $\mathrm{SiO}_{2}$ & Feldspars & $\mathrm{CaCO}_{3}$ & $\mathrm{Ca}(\mathrm{OH})_{2}$ & $\mathrm{CaSO}_{4}$ & $\mathrm{Fe}_{2} \mathrm{O}_{3}$ & $\mathrm{MgFeAlO}_{4}$ & Phosphates & Others \\
\hline \multicolumn{10}{|c|}{ Sec. cyklone ash } \\
\hline $\mathrm{Fe}+$ no lime & $X$ & $\mathrm{x}$ & & & & $\mathrm{X}$ & $\mathrm{x}$ & $\mathrm{Ca}_{9} \mathrm{Fe}\left(\mathrm{PO}_{4}\right)_{7}$ & \\
\hline $\mathrm{Fe}+$ limestone & $\mathrm{X}$ & $\mathrm{x}$ & $\mathrm{x}$ & & $\mathrm{x}$ & $\mathrm{X}$ & $\mathrm{x}$ & $\mathrm{Ca}_{9} \mathrm{Fe}\left(\mathrm{PO}_{4}\right)_{7}$ & \\
\hline Fe+hydr. lime & $\mathrm{X}$ & $\mathrm{x}$ & & & & $\mathrm{X}$ & & $\mathrm{Ca}_{9} \mathrm{Fe}\left(\mathrm{PO}_{4}\right)_{7}$ trace & $\mathrm{MgSiO}_{3}$ \\
\hline $\mathrm{Al}+$ no lime & $\mathrm{X}$ & $\mathrm{x}$ & $\mathrm{x}$ & & & & & & \\
\hline $\mathrm{Al}+$ limestone & $\mathrm{X}$ & $\mathrm{x}$ & $\mathrm{x}$ & & $\mathrm{x}$ & & & Possibly $\mathrm{AlPO}_{4}$ & \\
\hline Al+hydr. lime & $\mathrm{X}$ & $\mathrm{x}$ & & & $\mathrm{x}$ & & & $\mathrm{Ca}_{9} \mathrm{Al}\left(\mathrm{PO}_{4}\right)_{7}$ & \\
\hline \multicolumn{10}{|l|}{ Bag filter ash } \\
\hline $\mathrm{Fe}+$ no lime & $\mathrm{x}$ & & & & $\mathrm{x}$ & $\mathrm{X}$ & $\mathrm{x}$ & $\mathrm{Ca}_{9} \mathrm{Fe}\left(\mathrm{PO}_{4}\right)_{7}$ & $\mathrm{~K}_{0.4} \mathrm{Na}_{0.6} \mathrm{Cl}$ \\
\hline $\mathrm{Fe}+$ limestone & $\mathrm{x}$ & & $\mathrm{x}$ & & $\mathrm{x}$ & $\mathrm{X}$ & $\mathrm{x}$ & $\mathrm{Ca}_{9} \mathrm{Fe}\left(\mathrm{PO}_{4}\right)_{7}$ & \\
\hline Fe+hydr. lime & $\mathrm{x}$ & & & $\mathrm{X}$ & $\mathrm{x}$ & $\mathrm{X}$ & $\mathrm{x}$ & $\mathrm{Ca}_{9} \mathrm{Fe}\left(\mathrm{PO}_{4}\right)_{7}$ trace & $\mathrm{MgSiO}_{3}, \mathrm{~K}_{0.4} \mathrm{Na}_{0.6} \mathrm{Cl}$ \\
\hline $\mathrm{Al}+$ no lime & $\mathrm{x}$ & & $\mathrm{x}$ & & $\mathrm{X}$ & & & $\mathrm{Ca}_{9} \mathrm{Al}\left(\mathrm{PO}_{4}\right)_{7}$ & \\
\hline $\mathrm{Al}+$ limestone & $\mathrm{x}$ & $\mathrm{x}$ & $\mathrm{x}$ & & $\mathrm{X}$ & $\mathrm{x}$ & & $\mathrm{Ca}_{9} \mathrm{Al}\left(\mathrm{PO}_{4}\right)_{7}$ & \\
\hline $\mathrm{Al}+$ hydr. lime & $\mathrm{x}$ & & $\mathrm{x}$ & $\mathrm{X}$ & $\mathrm{x}$ & & & $\mathrm{Ca}_{9} \mathrm{Al}\left(\mathrm{PO}_{4}\right)_{7}$ trace & $\mathrm{Ca}_{3} \mathrm{Al}_{2} \mathrm{O}_{3}$ \\
\hline
\end{tabular}

\subsection{Release of phosphorous to the liquid phase in acid extraction.}

When the ashes were leached at $\mathrm{pH} 2.5$ only $22-30 \%$ of the phosphorus in the secondary cyclone ashes and $35-60 \%$ of that in the bag filter ashes was dissolved (Figure 4). By decreasing the $\mathrm{pH}$ to 1 , the phosphorus yield in the leachate of the secondary cyclone ash from sludge precipitated with aluminium sulphate increased to $74-95 \%$, whereas $49-65 \%$ of the phosphorous in ashes from iron based sludge could be extracted. Generally, at $\mathrm{pH} 1$, the phosphorus was easier extracted from the Al-rich ashes than from the Fe-rich ashes. At $\mathrm{pH} 2.5$ there was no significant difference observed between the ashes from the different cases. 


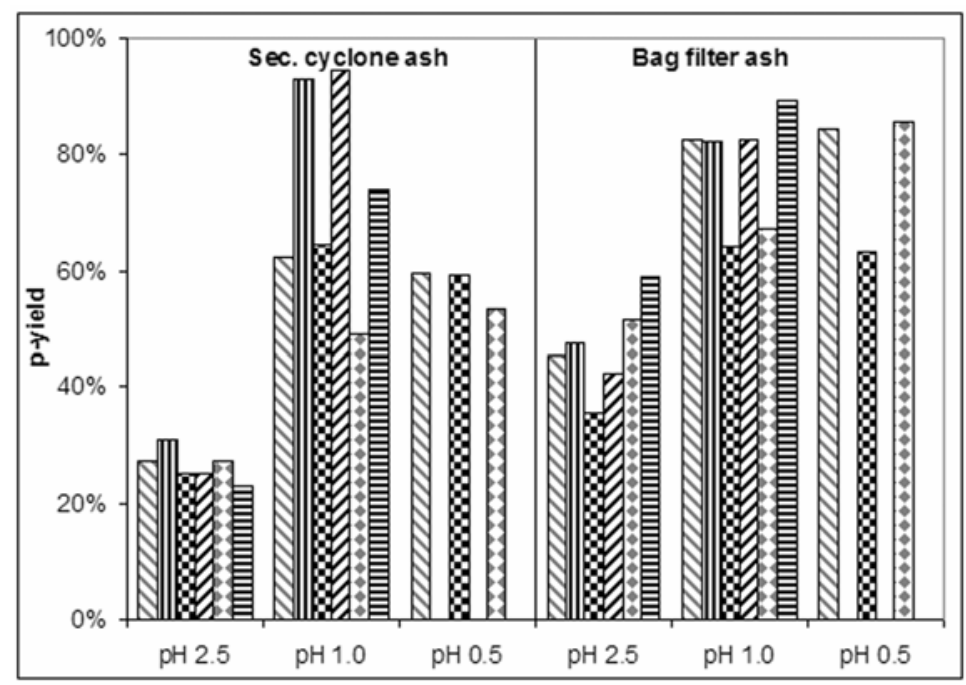

Figure 4: P-yield in leachate from secondary cyclone and bag filter ashes leached at different $\mathrm{pH}$. Only the ashes from iron based sludge were extracted at $\mathrm{pH}$ 0.5. $\mathbf{\mathrm { F } e}$ +no lime $\mathbf{m} \mathrm{Al}+\mathrm{no}$ lime $\mathrm{\mathbf {F }}$ Fe+limestone $\square \mathrm{Al}+$ limestone $\mathrm{Q} \mathrm{Fe}+$ hydr. lime $\mathrm{E} \mathrm{Al}+$ hydr. lime

The results from analysis of the leachate produced by extraction of both cyclone ash and bag filter ash at $\mathrm{pH} 1$ are presented in Table 8 .

Table 8: Main elements calculated on dry ash leached. Results from $\mathrm{pH} 1$.

\begin{tabular}{|c|c|c|c|c|c|c|c|c|c|c|c|c|}
\hline $\begin{array}{l}\text { Leachate anals } \\
\text { main elements } \\
\text { (g/kg dry ash) }\end{array}$ & $\begin{array}{l}\text { ysis } \\
\text { Fe+no lime } \\
\text { sec. cyclone }\end{array}$ & bag filter & $\begin{array}{l}\text { Al+no lime } \\
\text { sec. cyclone }\end{array}$ & bag filter & $\begin{array}{l}\text { Fe+limeston } \\
\text { sec. cyclone }\end{array}$ & bag filter & $\begin{array}{l}\text { Al+limeston } \\
\text { sec. cyclone }\end{array}$ & bag filter & $\begin{array}{l}\text { Fe+hydr. lim } \\
\text { sec. cyclone }\end{array}$ & bag filter & $\begin{array}{l}\text { Al+hydr. lime } \\
\text { sec. cyclone }\end{array}$ & bag filter \\
\hline $\mathrm{K}$ & 10 & 26 & 31 & 45 & 7.7 & 10 & 9.0 & 7.2 & 7.0 & 11 & 6.6 & 9.8 \\
\hline $\mathrm{Na}$ & 1.9 & 3.8 & 3.7 & 4.1 & 1.4 & 2.6 & 1.9 & 1.6 & 2.2 & 1.2 & 1.9 & 1.5 \\
\hline $\mathrm{Al}$ & 19 & 26 & 63 & 37 & 17 & 22 & 56 & 35 & 14 & 10 & 53 & 18 \\
\hline $\mathrm{Si}$ & 4.3 & 13 & 26 & 34 & 3.9 & 11 & 14 & 19 & 3.6 & 8.2 & 14 & 13 \\
\hline $\mathrm{Fe}$ & 5.1 & 6.4 & 6.1 & 5.2 & 5.7 & 5.8 & 5.7 & 7.2 & 5.8 & 3.2 & 5.7 & 4.0 \\
\hline $\mathrm{Ca}$ & 43 & 85 & 45 & 134 & 59 & 77 & 85 & 115 & 42 & 154 & 43 & 125 \\
\hline $\mathrm{Mg}$ & 5.1 & 10 & 4.0 & 15 & 5.4 & 7.5 & 3.0 & 5.9 & 6.0 & 6.9 & 3.1 & 6.9 \\
\hline$P$ & 41 & 47 & 56 & 32 & 39 & 36 & 56 & 42 & 32 & 15 & 47 & 15 \\
\hline $\mathrm{Ti}$ & 0.15 & 0.24 & 0.28 & 0.55 & 0.12 & 0.24 & 0.15 & 0.26 & 0.11 & 0.20 & 0.15 & 0.33 \\
\hline
\end{tabular}

In order to investigate whether the phosphorus could be extracted to a greater extent from iron based sludge ashes even more acidic conditions were used in some additional leaching tests where the $\mathrm{pH}$-value was decreased to only 0.5 . In Figure 4 these results are included. Only the bag filter ash "Fe+hydr. lime" gave an increased phosphorus yield, $85 \%$ as compared to $68 \%$ at pH 1 (Figure 4). For the secondary cyclone ashes the release of phosphorous was still fairly poor using the lower $\mathrm{pH}$-value. This is consistent with the results obtained by Matsuo [15] when investigating how an addition of ferric chloride, $\mathrm{FeCl}_{3}$, to the sludge, prior to combustion, could be used to prevent phosphorus release from the sludge ash in a land fill. However, it was not reported by Matsuo [15], how the iron chemically stabilized the phosphorus.

There are no clear tendencies in the results showing that the solubility of phosphorus can be related to the supply of limestone to the bed or to hydrated lime added to the bag filter; only 
minor effects of the lime were observed. This means that active sulphur capture strategies (limestone to the bed or hydrated lime to a bag filter) can be adopted without disturbing an active phosphorous recovery strategy such as leaching at low $\mathrm{pH}$-values using aluminium sulphate as precipitation agent at the waste water treatment plant.

\subsection{Equilibrium calculations.}

Equilibrium calculations using the Hydra/Medusa program package [11] showed that three solid compounds may influence the recovery of phosphorus in the liquid phase: $\mathrm{FePO}_{4}: 2 \mathrm{H}_{2} \mathrm{O}$, $\mathrm{CaHAl}\left(\mathrm{PO}_{4}\right)_{2}$ and $\mathrm{Ca}_{5}\left(\mathrm{PO}_{4}\right)_{3} \mathrm{OH}$. These compounds may precipitate from the solution in different $\mathrm{pH}$ intervals, thus preventing the phosphorus from ending up in the extraction product. The ferric phosphate could form at a $\mathrm{pH}$ below 4.2, the calcium aluminium phosphate in the $\mathrm{pH}$ range 4.2 to 6 and hydroxyl apatite $\left(\mathrm{Ca}_{5}\left(\mathrm{PO}_{4}\right)_{3} \mathrm{OH}\right)$ at a $\mathrm{pH}$ level over 6 . This means that, theoretically, there is no $\mathrm{pH}$ window where the phosphorous extraction would not be disturbed by precipitation of a solid phosphate. The amount of phosphorous bound in these solid compounds depends on the amounts of $\mathrm{Fe}^{3+}, \mathrm{Al}^{3+}$ and $\mathrm{Ca}^{2+}$ available in the water phase and $\mathrm{pH}$. The interference from precipitation would be most serious for ash from iron based sludge, but the ash from aluminium based sludge would also be affected since it contains significant amounts of iron as well (Table 1). However, the experimental results showed that phosphorous could actually be extracted and kept in solution. In addition, the amount of ferric iron released to the leachate was very low in all experiments: less than $5 \%$ for ashes from iron based sludge and less than $20 \%$ for the aluminium based.

In the present case, the dominant iron compound in the ashes is haematite $\left(\mathrm{Fe}_{2} \mathrm{O}_{3}\right)$. Haematite is theoretically not soluble at $\mathrm{pH}$ above 1.5 , but it is soluble at lower $\mathrm{pH}$. The low concentration of iron in the leachates indicates that the dissolution kinetics of the hematite present in the ashes is too slow and consequently the amount of ferric ions available for formation of solid $\mathrm{FePO}_{4} \cdot 2 \mathrm{H}_{2} \mathrm{O}$ is small. This is favourable for the extraction of phosphorous.

This is illustrated in Figure 5, where theoretically possible concentrations of dissolved $\mathrm{Al}, \mathrm{Fe}, \mathrm{Ca}$ and $\mathrm{P}$ are compared with those found in experiments on the "Fe+no lime" secondary cyclone ash at $\mathrm{pH} 0.5,1$ and 2.5 . 


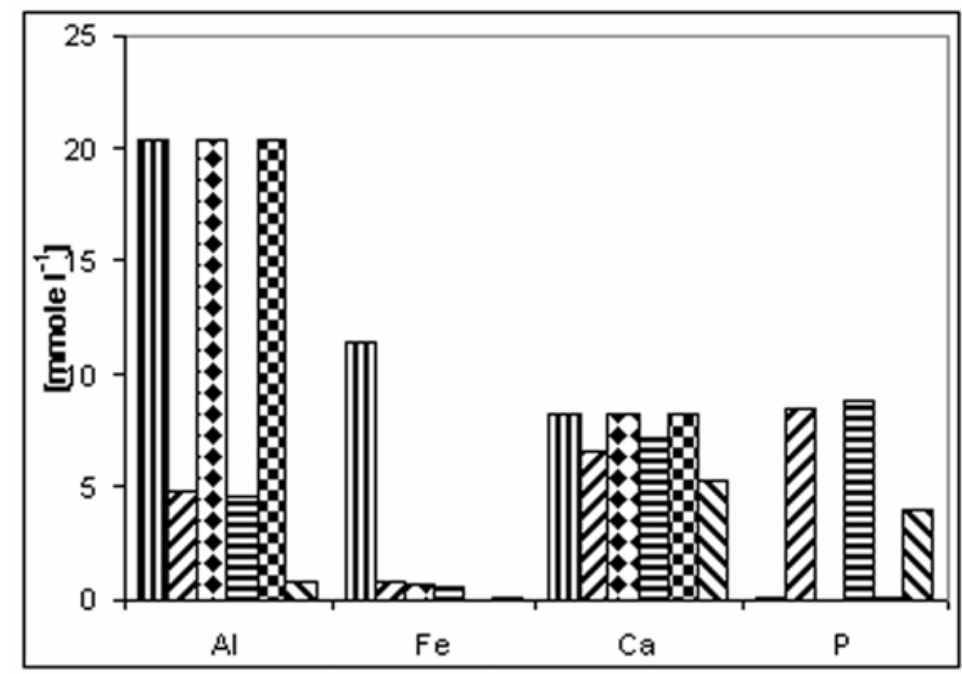

Figure 5: Comparison of the calculated (equilibrium) and experimental (measured) concentrations of dissolved compounds at $\mathrm{pH} 0.5,1$ and 2.5. Ash sample "Fe+no lime" secondary cyclone.

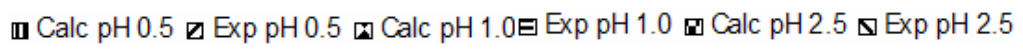

Both iron and aluminium were found in much lower amounts than the theoretical in the leachates, whereas the calcium content approximately corresponded to the equilibrium content and the phosphate content was much higher than theoretically expected.

The solubility of aluminium compounds present in the ashes is important, not only for its possible reactions with phosphate, but also for its possible effect on the environment. Aluminium ions $\left(\mathrm{Al}^{3+}\right)$ released to a soil could have detrimental effects on plants growing on that soil. The aluminium ions will probably be bound in different minerals or precipitate as aluminium hydroxide in suitable $\mathrm{pH}$ ranges, but there is a risk of plant uptake at certain conditions [16].

The investigation of the untreated and extracted ashes with the electron microscope indicated both physical and chemical transformations during leaching. Figure 6a shows the electron microscopy pictures of the original ash "Fe+limestone" and Figure $6 \mathrm{~b}$ the ash after leaching. The corresponding element maps are given in Figure $7 \mathrm{a}$ and $7 \mathrm{~b}$. From both these sets of figures it is evident that the original ash consists of well defined, individual particles whereas the leached ash contains agglomerated clusters of small particles sticking to the surfaces of the larger ones. 

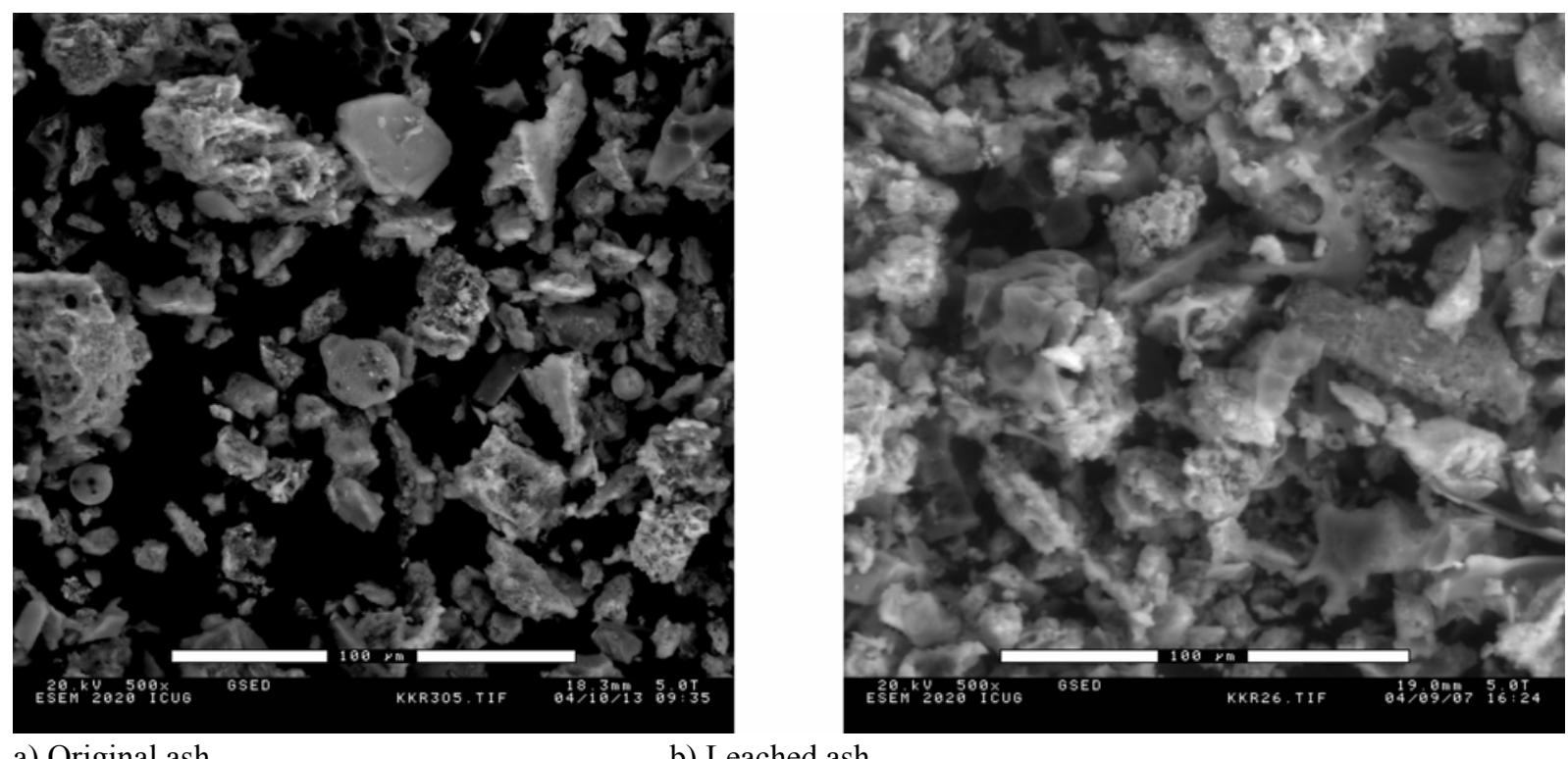

a) Original ash

b) Leached ash

Figure 6: Electron microscopy pictures comparing the cyclone ash (a) "Fe+limestone" in its original form and (b) after leaching.
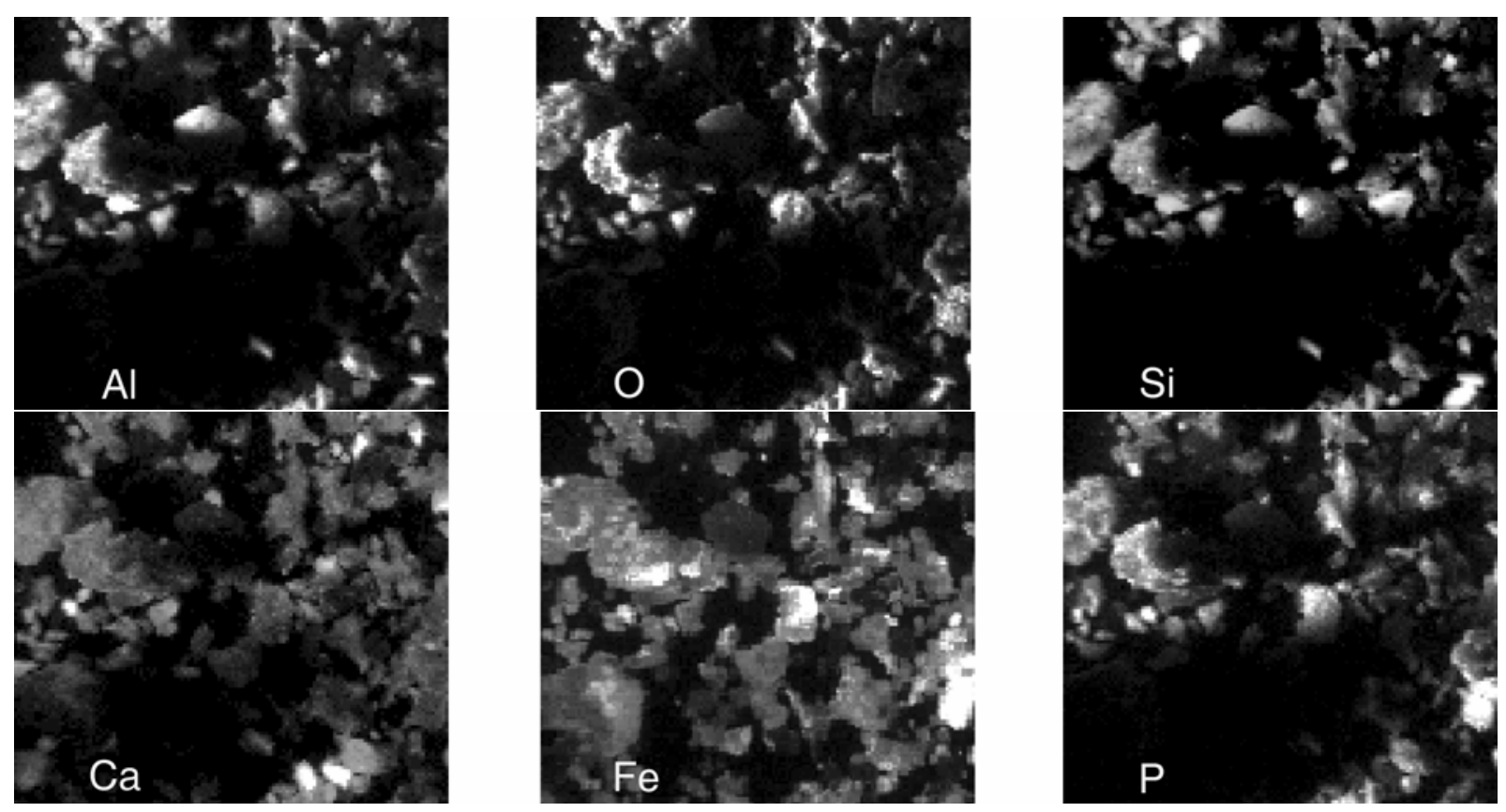

Figure 7a: SEM-EDX element maps for the cyclone ash "Fe+limestone". 

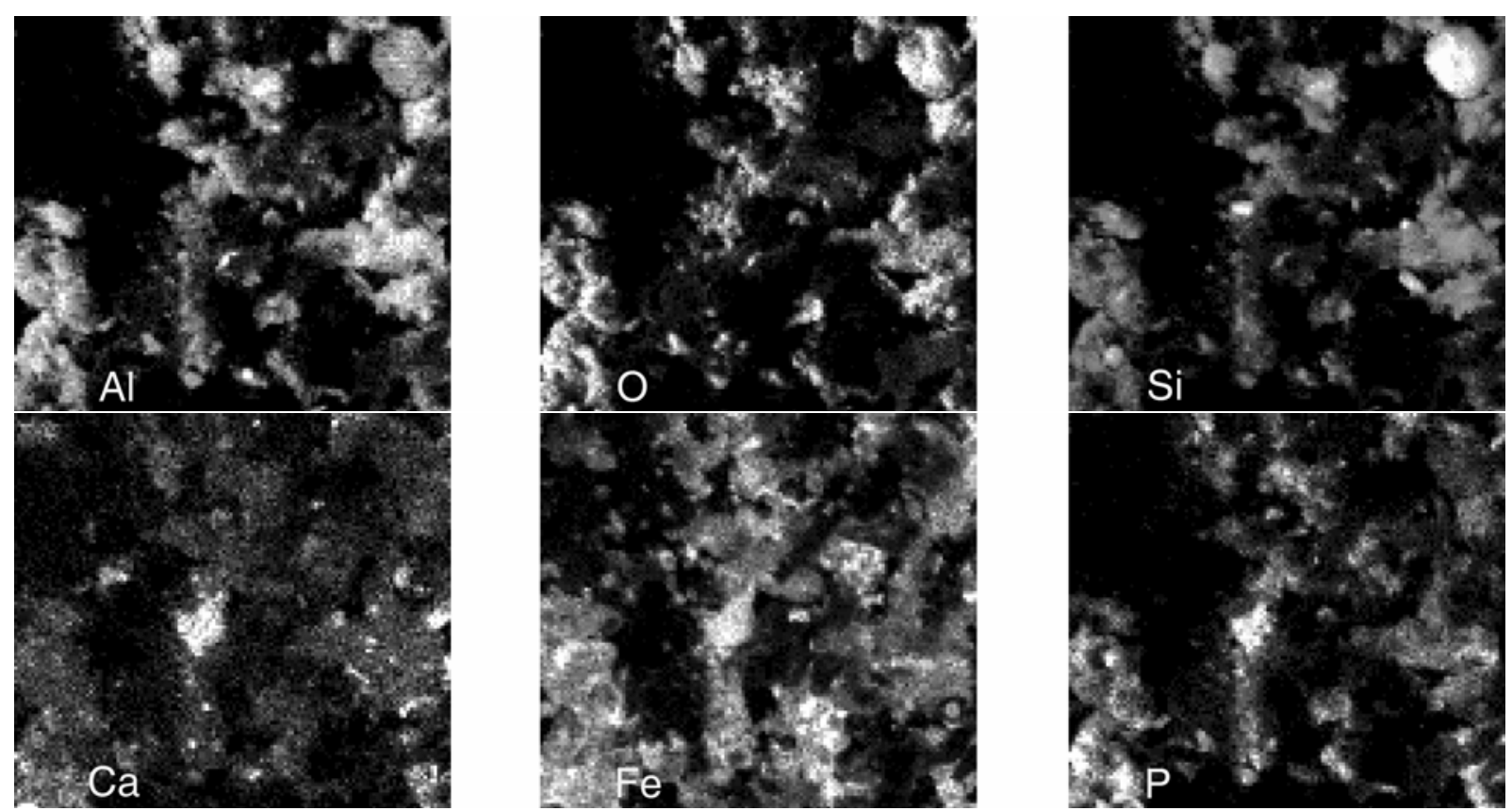

Figure 7b: SEM-EDX element maps for the solid residue after leaching of the cyclone ash "Fe+limestone" at pH 2.

The element maps support the findings of iron oxide and calcium iron phosphate using XRD analysis (Table 7). These compounds seem to survive the leaching procedure (Figure 7b) to some extent. This makes sense in the light of the low leachability of Fe showed in Figure 5. The experimental results show that combustion of the sewage sludge followed by extraction of the ashes to recover phosphorous is a better procedure than using the sludge directly as a soil fertiliser considering the possibility to exclude aluminium from the flow of metals to the agricultural soil. The chemistry of trace metals in ash from sewage sludge and wood will be further discussed in part 2 [1] of the project.

\subsection{Comparison with other methods of phosphorous recovery from sewage sludge.}

As mentioned in the introduction, there are a few other processes proposed for recovery of phosphorus from sewage sludge or from ashes from combustion of sludge: the BioCon-process recovering phosphorus and iron sulphate from incinerated sewage sludge and the KREPRO and Cambi/KREPRO processes in which phosphorous is extracted by acid from hydrolysed sludge [5; $6]$. Due to large consumption of chemicals in combination with high energy demand, none of these processes are economically feasible at present. Hultman and co-workers [17] made a theoretical comparison of different techniques for recovery of phosphorus applied to a specific waste-water plant. They suggested solutions and compared estimated consumptions of chemicals, based on data from pilot-plants where the BioCon and KREPRO processes have been tested. In these processes most compounds in the ash or sludge are dissolved, in contrary to the method used in the present study, where the purpose is to find a $\mathrm{pH}$ at which only the phosphorus compounds dissolve. The sludges compared in the present study and in the study of Hultman et al. have approximately the same concentration of phosphorus and the recovery is estimated to 
$80 \%$ in both cases. The calculations of Hultman et al. allow a comparison of BioCon and the method used here, as presented in Figure 8. The figure shows the amount of chemicals, based on the number of acid equivalents (represented by $\mathrm{H}^{+}$), required to neutralise the alkalinity of a certain mass of ash and to transfer the cat ions in Table 9 into the water phase.

Table 9: The $\mathrm{H}^{+}$required for dissolving (hydrolysation) of different compounds containing $\mathrm{Fe}, \mathrm{Al}, \mathrm{Ca}$ and $\mathrm{Mg}$ represented by the corresponding hydroxides.

\begin{tabular}{cccc}
\hline & ekv. $\mathrm{H}^{+} / \mathrm{mol}$ & ekv. $\mathrm{H}^{+} / \mathrm{mol}$ \\
\hline $\mathrm{Fe}(\mathrm{OH})_{3}$ & 3 & $\mathrm{Ca}(\mathrm{OH})_{2}$ & 2 \\
$\mathrm{Al}(\mathrm{OH})_{3}$ & 3 & $\mathrm{Mg}(\mathrm{OH})_{2}$ & 2 \\
\hline
\end{tabular}

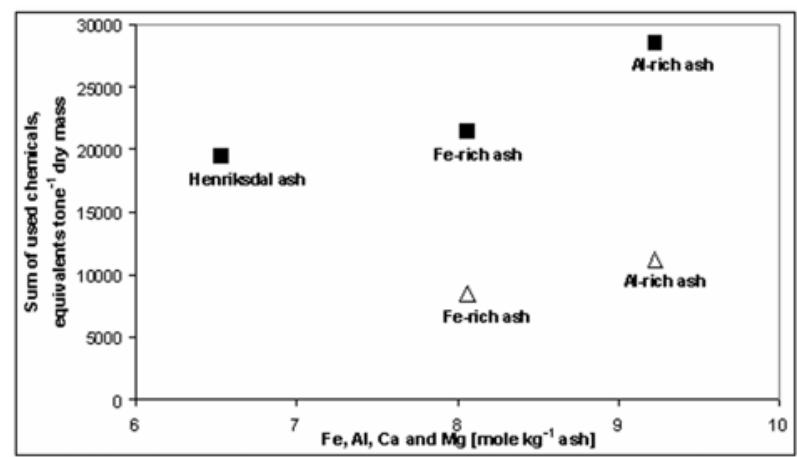

Figure 8: Calculated chemical consumption for Henriksdal ash [17] and calculated chemical consumption for the ashes in this study if using the BioCon-process (Black symbols) compared with the actual chemical demand in this study (Open symbols). One equivalent is one mole of $\mathrm{H}^{+}$.

Hultman et al. estimated the amount of chemicals needed to dissolve $\mathrm{Ca}, \mathrm{Fe}, \mathrm{Al}$ and $\mathrm{Mg}$ for Henriksdal [17]. This case, completed by the cases with Fe-rich ash and Al-rich ash from the present study, is shown by the black squares in Figure 8. The corresponding consumption of chemicals for the present technique is shown as open triangles. The final products obtained with the BioCon-process are phosphoric acid, iron chloride, potassium bisulphate and sand, whereas the products of the present technique are not refined to that extent.

If applying the ion-exchange technology of the BioCon-process on the leachate from the present technique, the amount of chemicals needed would still be much lower than in the Biocon process.

Recently, a new process has been suggested: the SEPHOS-process [7;8]. That process is the one most corresponding to the present work. In the SEPHOS-process sewage sludge ash is treated with sulphuric acid at $\mathrm{pH}<1.5$, both parameters similar to what is tested in this study. The solid residues are separated and the $\mathrm{pH}$ of the filtrate is stepwise increased to 3.5 by addition of caustic soda. The elevated $\mathrm{pH}$ causes a precipitation of aluminium phosphate diluted with most of the trace metals dissolved in the initial step. Due to lack of information about this process a comparison with the other processes in Figure 8 is not possible. 


\section{Conclusions}

The results obtained in this work showed that the phosphorus is more concentrated in the fly ash than in the bed ash. Generally, $75-98 \%$ of the phosphorous leaving the CFB boiler is retained in the fly ash. Therefore, the development of a process for recovery of phosphorous should be focused on fly ash.

The phosphorus in the ash is easier to extract if the precipitation agent in the water treatment plant is aluminium sulphate instead of iron sulphate. The $\mathrm{pH}$-value has to be low (about 1) to achieve above $50 \%$ yield of phosphorus in the leachate from ashes of sludge precipitated by $\mathrm{Fe}$ in short-time leaching, suitable for an industrial process. A similar $\mathrm{pH}$ gives a phosphorus yield of 75 to $95 \%$ from ash originating from Al-precipitated sludge. The low $\mathrm{pH}$ suitable for leaching has to be increased if the leachate is to be used as fertiliser.

The benefits of the present method are 1) co-combustion of sewage sludge and wood that makes it possible to use the calorific value of the sewage sludge for heat production, 2) the destruction of organic toxic compounds and 3) the phosphorus recovery technique with low consumption of chemicals that allows utilisation of the phosphorus in the ashes.

Moreover, the performance of this method is not affected by the common sulphur capture strategies employed in fluidized bed boilers.

\section{Acknowledgments}

This work was performed with financial support from the Swedish Energy Administration and the KK-Foundation. The practical performance of the tests were carried out with support from the operating staff of Akademiska Hus AB and the research staff at the Department of Energy and Environment division of Energy Technology Chalmers University of Technology which is gratefully acknowledged.

\section{References}

[1] Pettersson A, Åmand L-E, Steenari B-M. Leaching of ashes from co-combustion of sewage sludge and wood. Part II: The mobility of metals during phosphorous extraction. 2007, Submitted to Biomass and Bioenergy.

[2] Brett S, Guy J, Morse G K, Lester J N. Phosphorus removal and recovery technologies. Environmental and Water Resource Engineering Section, Imperial College of Science, Technology and Medicine, 1997, London SW7 2BU, ISBN 0948411100.

[3] Eriksson J. Concentrations of 61 Trace elements in sewage sludge, farmyard manure, mineral fertiliser, precipitation and in soil and crops. Report 5159, 2001, Swedish Environmental Protection Agency, Stockholm, ISBN 91-620-5159-8, ISSN 0282-7298.

[4] Åmand L-E, Leckner B. Metal Emissions from Co-Combustion of Sewage Sludge and Coal/Wood in Fluidized Bed. Fuel 2004;83:1803-1821.

[5] Hansen B, Karlsson I, Cassidy S, Pettersson L. Operational experiences from a sludge recovery plant. Water Science and Technology 2000;41(8):23-30. 
[6] Hultman B, Levin E, Mossakowska A, Stark K. Effects of wastewater treatment technology on phosphorus recovery from sludges and ashes. Second International Conference on Recovery of Phosphates from Sewage and Animal Wastes. 2001, Noordwijkerhout, Netherlands.

[7] Berg U, Schaum C. Recovery of phosphorus from sewage sludge and sludge ashesapplications in Germany and northern Europe. Proceedings of the $1^{\text {th }}$ National Sludge Symposium, 23-25 March 2005, p. 87-98, Izmir, Turkey.

[8] Schaum C, Cornel P, Jardin N. Possibilities for a phosphorus recovery from sewage sludge ash. Management of Residues from Water and Wastewater Treatment, 9-12 August 2005, Johannesburg, South Africa.

[9] Pettersson A, Åmand L-E, Andersson B-Å, Steenari, Leckner B. Leaching of phosphorus from ashes of co-combustion of sewage sludge and wood. Proc. of $18^{\text {th }}$ International Conference of Fluidized Bed Combustion, American Society of Mechanical Engineers (ASME), Toronto, Canada, 22-25 May 2005, Paper FBC05-78017. http://members.asme.org/catalog/CategoryView.cfm

[10] Yoshizaki S, Tomida T. Principle and process of heavy metal removal from sewage sludge. Environmental Science and Technology 2000;34(8):1572-1575.

[11] Puigdomenech I, Hydra/Medusa version 2004-02-18, http://www.kemi.kth.se/medusa/.

[12] Åmand L-E, Leckner B, Hansson L, Norrlöw O. Co-combustion of municipal sludge with wood/coal in CFB - enrichment of phosphorous and cadmium in ashes. Proc. of the $17^{\text {th }}$ International Conference on Fluidized Bed Combustion, ASME, New York, May 2003, Paper FBC03-0098.

[13] Elled A-L, Åmand L-E, Leckner B, Andersson B-Å. The fate of trace elements in fluidized bed combustion of sewage sludge and wood. Fuel 2007;86(5-6):843-852.

[14] Elled A-L, Åmand L-E, Leckner B, Andersson B-Å. Influence of phosphorus on sulphur capture during co-firing of sewage sludge with wood or bark in a fluidized bed, Fuel 2006; 85(12-13):1671-1678.

[15] Matsuo Y. Release of phosphorus from ash produced by incinerating waste activated sludge from enhanced biological phosphorus removal. Water Science and Technology 1996;34(12):407-415.

[16] Kinraide T B, Sweeney B K. Proton alleviation of growth inhibition by toxic metals (Al, La, $\mathrm{Cu}$ ) in rhizobia. Soil Biology and Biochemistry 2003;35(2):199-205.

[17] Hultman B, Levin E, Löwén M, Mossakowska A, Stark K. Utvinning av fosfor och andra produkter ur slam och aska, [Recovery of phosphorus and other products from sludge and ash]. Stockholm Vatten AB, Sweden, March 2001. Report nr. 6. 